\title{
DUKUNGAN SOSIAL TERHADAP KONSUMSI ARV IBU RUMAH TANGGA PENDERITA HIV DI SURABAYA
}

\author{
SOCIAL SUPPORT FOR ARV CONSUMPTION OF HOUSEWIFE \\ WITH HIV IN SURABAYA
}

\author{
Nurina Ayu Dewi Puspita Sari, Ira Nurmala \\ Departemen Promosi Kesehatan dan Ilmu Perilaku, \\ Fakultas Kesehatan Masyarakat, Universitas Airlangga, Surabaya \\ Email: nurina.ayu75@gmail.com
}

\begin{abstract}
In 2014, East Java ranks second highest HIV cases in Indonesia to 32.872 the number of HIV cases. Concern HIV disease is exposed when in 2014 based on the sequence of work housewife ranks second HIV cases in Surabaya with the number of 129 cases. The case of a housewife who has HIV is higher compared to commercial sex workers. Therapeutic treatment for patients with HIV using antiretroviral drugs. ARV consumption serves to suppress the growth of HIV. This study was conducted to determine the social support for the consumption of ARV housewife in Surabaya. The research is a qualitative research with case study approach. Informants used are numbered 9 consisting of three housewives with HIV, three families and three close friends housewife with HIV. The study was conducted from May to December 2016. Data collection using an interview guide and study documents. The results showed that there is social support for the consumption of housewives with HIV. Their differences in background, control beliefs, perceived behavioral control, intention-owned and social support received informants could affect the consumption of ARVs do informant. The conclusion that can be drawn is that the most influential social support for the consumption of ARV housewife with HIV in Surabaya is emotional support and support networks. Another effect of ARV consumption comes from a background that was once owned by housewives with HIV.
\end{abstract}

Keywords: social support, consumption of ARV, housewife, HIV

\begin{abstract}
Abstrak: Tahun 2014, Jawa Timur menempati posisi kedua kasus HIV terbanyak di Indonesia dengan jumlah kasus HIV 32.872. Keprihatinan penyakit HIV menjadi bertambah ketika tahun 2014 berdasarkan urutan pekerjaan ibu rumah tangga menempati posisi kedua kasus HIV di Surabaya dengan jumlah 129 kasus. Kasus ibu rumah tangga yang terkena HIV lebih tinggi dibandingkan dengan pekerja seks komersial. Terapi pengobatan bagi penderita HIV menggunakan ARV. Konsumsi ARV berfungsi untuk menekan jumlah pertumbuhan virus HIV Penelitian ini dilakukan untuk mengetahui dukungan sosial terhadap konsumsi ARV ibu rumah tangga di Surabaya. Jenis penelitian ini adalah penelitian kualitatif dengan pendekatan studi kasus. Informan yang digunakan adalah berjumlah 9 yang terdiri dari $3 \mathrm{ibu}$ rumah tangga penderita HIV, 3 keluarga dan 3 teman dekat ibu rumah tangga penderita HIV. Penelitian ini dilaksanakan pada bulan Mei hingga bulan Desember 2016. Pengambilan data dengan menggunakan panduan wawancara dan studi dokumen. Hasil penelitian menunjukkan bahwa terdapat dukungan sosial terhadap konsumsi ibu rumah tangga penderita HIV. Adanya perbedaan latar belakang, control beliefs, perceived control behavioural, niatan yang dimiliki dan dukungan sosial yang diterima informan dapat mempengaruhi konsumsi ARV yang dilakukan informan. Kesimpulan yang dapat ditarik adalah dukungan sosial yang paling berpengaruh terhadap konsumsi ARV ibu rumah tangga penderita HIV di surabaya adalah emotional support dan networks support. Pengaruh lain konsumsi ARV berasal dari latar belakang yang pernah dimiliki oleh ibu rumah tangga penderita HIV.
\end{abstract}

Kata kunci: dukungan sosial, konsumsi ARV, ibu rumah tangga, HIV

\section{PENDAHULUAN}

Kesehatan adalah hal yang paling penting untuk kehidupan manusia, karena ketika manusia sehat maka bisa melakukan kegiatan yang produktif. Seiring perkembangan jaman, penyakit pada manusia semakin banyak dan kompleks. 
Banyak penyakit yang dapat menimbulkan kematian pada manusia seperti penyakit HIV AIDS. HIV adalah singkatan dari Human Immunodeficiency Virus, yaitu virus yang menyerang sel darah putih yang bernama sel CD4 sehingga merusak sistem kekebalan tubuh. AIDS berasal dari singkatan Acquired Immune Deficiency Syndrome adalah dampak atau efek dari perkembangbiakan virus HIV dalam tubuh makhluk hidup. Sindrom AIDS dapat timbul karena melemahnya sistem kekebalan tubuh yang banyak dirusak oleh Virus HIV (Depkes RI, 2003).

Data kasus HIV tahun 2014 di Indonesia adalah DKI Jakarta berada di posisi pertama dengan jumlah 32.872 kasus, posisi kedua adalah Jawa Timur dengan 19.249 kasus, dan posisi ketiga adalah Papua dengan 16.051 kasus (Kemenkes RI, 2014). Kasus HIV di Surabaya dari tahun 2007-2014 terjadi peningkatan setiap tahunnya. Kasus HIV tertinggi terjadi pada tahun 2014 dengan kasus 572. Jumlah Kasus HIV di Surabaya berdasarkan pekerjaan pada ibu rumah tangga menempati urutan kedua dengan jumlah kasus 129.Kasus HIV pada ibu rumah tangga lebih tinggi daripada pekerja seks komersial (PSK) yang berjumlah 33 kasus. Kasus HIV terbanyak d kota Surabaya yaitu pada pekerjaan wiraswasta dengan jumlah kasus 204 (Dinkes Kota Surabaya, 2014).

Sumber penularan utama HIV pada ibu rumah tangga adalah dari pasangan atau suami mereka sendiri. Kerentanan ibu rumah tangga tertular HIV AIDS disebabkan oleh ketimpangan gender yang berdampak pada ketidakmampuan istri dalam mengontrol perilaku seksual yang dilakukan oleh suami, seperti membeli jasa pekerja seks komersial dan menjadi pengguna narkoba jarum suntik (Penasun). Berdasarkan data disebutkan bahwa heteroseksual merupakan penyebab utama penyebaran HIV (Kemenkes, 2013). Ibu rumah tangga selama ini digolongkan ke dalam kelompok non risiko Selama ini upaya pemberantasan HIV berfokus pada kelompok risiko seperti pekerja seks komersial, pemakai narkoba suntik dan homoseksual.

Banyaknya anggapan di masyarakat bahwa perempuanlah sebagai penyebab dan penyebar utama HIV membuat stigma yang ada di masyarakat terhadap perempuan yang terkena HIV sangat buruk (Hollen, 2010). Hal ini membuat seseorang yang terkena HIV biasanya akan menarik diri dari masyarakat hal ini terjadi karena ada perasaan takut dan tidak bisa menerima status HIV nya. Seseorang akan lebih menarik diri dan menjadi pribadi yang tertutup apabila ditambah adanya stigma pada dirinya.

Tingginya kasus HIV pada ibu rumah tangga membutuhkan adanya kesadaran dan keyakinan diri penderita HIV untuk mengonsumsi antiretroviral (ARV) secara rutin. Konsumsi ARV secara rutin tidak bertujuan untuk menghilangkan virus HIV yang ada tetapi untuk menekan jumlah pertumbuhan virus HIV di tubuh. Ketika individu yang terkena HIV rutin minum ARV maka jumlah viral load dalam tubuh menjadi rendah. Individu menjadi lebih sehat dan kemungkinan untuk menularkan virus HIV menjadi lebih sedikit sehingga ibu rumah tangga harus mempunyai kesadaran untuk minum ARV.

Dukungan sosial diperlukan agar ibu rumah tangga penderita HIV mau untuk mengonsumsi ARV. Ibu rumah tangga penderita HIV harus punya kesadaran untuk sembuh yang dimulai dari control beliefs bahwa penderita HIV percaya dengan manfaat mengonsumsi ARV secara teratur. Dukungan sosial sangat diperlukan oleh penderita HIV AIDS, hal ini dapat dilihat sesuai dengan penelitian yang dilakukan oleh Rahadatu (2016) bahwa ada hubungan positif antara dukungan sosial dengan kualitas hidup pada penderita HIV AIDS pada KDS Solo Plus yaitu semakin baik dukungan sosial yang diterima maka kualitas hidup semakin meningkat. Berdasarkan latar belakang yang ada, penelitian ini memiliki tujuan melihat dukungan sosial yang diterima oleh ibu rumah tangga penderita HIV terhadap konsumsi ARV.

\section{METODE}

Jenis penelitian yang digunakan adalah penelitian kualitatif dengan menggunakan pendekatan studi kasus. Tujuan penelitian ini untuk mengetahui peran dukungan sosial terhadap konsumsi ARV ibu rumah tangga 
penderita HIV. Pelaksanaan penelitian ini berlangsung pada bulan mei 2016 sampai bulan desember 2016. Penelitian ini dilakukan di kota Surabaya.

Populasi dalam penelitian ini adalah ibu rumah tangga penderita HIV di Surabaya. Teknik pengambilan informan dengan menggunakan kriteria inklusi yaitu ibu rumah tangga dengan usia 25-49 tahun, tempat tinggal di Surabaya, positif menderita HIV yang tertular dari suami, open status dan mendapat dukungan sosial dari keluarga dan lingkungannya. Penelitian ini menggunakan 9 informan yang terdiri dari 3 ibu rumah tangga penderita HIV, 3keluarga, dan 3 teman dekat ibu rumah tangga penderita HIV.

Penelitian ini dilaksanakan dengan wawancara mendalam dan studi dokumen. Wawancara dilakukan dengan menggunakan panduan wawancara. Untuk menjamin validitas data dan kredibilitas dalam penelitian ini, menggunakan triangulasi sumber dan studi dokumen. Cara melakukan validitas data dengan pengecekan atau membandingkan terhadap hasil wawancara yang diperoleh dari sumber diluar wawancara itu, untuk meningkatkan keabsahan data (Moleong, 2009).

Hasil penelitian ini disesuaikan dengan menggunakan Theory of Planned Behavior dengan melihat latar belakang, control belief, perceived control behavior, intention, perilaku ibu rumah tangga dalam konsumsi ARV dan dukungan yang diterima oleh ibu rumah tangga.

\section{HASIL}

Berdasarkan hasil penelitian, informan berjumlah 9 yang terdiri dari 3 ibu rumah tangga penderita HIV yang penularannya berasal dari suami, 3 keluarga dari ibu rumah tangga dan 3 teman dekat ibu rumah tangga penderita HIV.

Berdasarkan Tabel 1 pada tingkat pendidikan dapat disimpulkan bahwa semua informan telah menyelesaikan pendidikan dasar 12 tahun dan dianggap memiliki pengetahuan dasar pada pendidikan formal. Berdasarkan hasil wawancara, ibu rumah tangga penderita HIV dapat menjawab dengan benar tentang pengertian penyakit
Tabel 1. Klasifikasi Umur dan Pendidikan Informan

\begin{tabular}{lcc}
\hline \multicolumn{1}{l}{ Nama Inisial } & \multicolumn{1}{c}{ Umur } & Pendidikan \\
\hline \multicolumn{2}{l}{ Ibu rumah tangga } \\
Ny A & 42 Tahun & SMK \\
Ny B & 35 Tahun & SMK \\
Ny C & 43 Tahun & D3 \\
\hline \multicolumn{2}{l}{ Keluarga ibu rumah tangga } \\
An D & 18 Tahun & SMA \\
Tn H & 41 Tahun & SMA \\
An F & 20 Tahun & SMA \\
\hline Teman dekat ibu rumah tangga & \\
Ny G & 34 Tahun & SMA \\
Ny E & 36 Tahun & SMA \\
Tn I & 47 Tahun & SMA \\
\hline
\end{tabular}

HIV bahwa HIV(Human Imunodeficiency Virus) adalah virus yang menyerang sistem kekebalan tubuh pada manusia. Ibu rumah tangga penderita HIV telah memahami cara penularan penyakit HIV yaitu dari penggunaan jarum suntik bergantian dan berhubungan seksual. Salah satu ibu rumah tangga penderita HIV mempunyai pendapat bahwa selain dua penularan tersebut, penyakit HIV bisa ditularkan dari ibu ke anaknya ketika menyusui ada lecet pada putting maka anaknya dapat tertular HIV. Prinsip pencegahan HIV sudah diketahui oleh ibu rumah tangga penderita HIV, tetapi Prinsip pencegahan HIV dapat dijelaskan secara lengkap oleh salah satu ibu rumah tangga penderita HIV yaitu A, B, C, D Abstinence, Be Faithful, using Condom dan Don't Use Drug.

Jenis media informasi yang digunakan oleh ibu rumah tangga penderita HIV untuk mengakses informasi tentang penyakit HIV AIDS sangat beragam. Berdasarkan hasil wawancara, ibu rumah tangga penderita HIV mencari informasi tentang HIV AIDS dengan mengikuti pertemuan yang diadakan oleh komunitas penderita HIV AIDS, sosialisasi yang diadakan oleh Dinas Kesehatan Kota Surabaya, membaca buku HIV AIDS dari LSM Mahameru, media sosial, dan mengikuti seminar. Pertemuan yang diikuti oleh informan adalah pertemuan yang diadakan oleh Kelompok Dukungan Sebaya (KDS) selama 1 bulan sekali biasanya ada sosialisasi yang dilakukan tenaga kesehatan. Saat pertemuan 
berlangsung ibu rumah tangga penderita HIV saling berbagi cerita kepada temantemannya terkait penyakit HIV sehingga bisa mengurangi stres karena permasalahan yang dihadapi.

Pengalaman penyakit HIV yang dialami oleh ibu rumah tangga penderita HIV beraneka macam. Dua ibu rumah tangga penderita HIV mendapatkan risiko penyakit HIV dari suaminya yang menjadi pengguna narkoba suntik dan satu ibu rumah tangga penderita HIV terkena dari suaminya yang melukan seks berganti pasangan saat bekerja di luar kota. Setiap ibu rumah tangga penderita HIV memiliki pengalaman dalam konsumsi ARV yang berbeda.

Kontrol kepercayaan (control beliefs) yang kuat terhadap konsumsi ARV. Keyakinan yang dimiliki ibu rumah tangga penderita HIV untuk konsumsi ARV beragam. Hal ini terlihat dari pernyataan ibu rumah tangga penderita HIV sebagai berikut:

“...saya percaya kalau ARV itu fungsinya besar mbak dan kita gak boleh putus harus minum sampai kapanpun..." (Ny A, 42 Tahun, P)

Tidak hanya pengalaman dari temanteman saja, ibu rumah tangga penderita HIV juga mendapat pengalaman seseorang yang putus ARV dan akhirnya meninggal dari suaminya. Control beliefs yang dimiliki oleh ibu rumah tangga penderita HIV berasal dari pengalaman suami dan teman-temannya. Pengalaman inilah yang membuat ibu rumah tangga penderita HIV memiliki kepercayaan bahwa minum ARV memiliki fungsi dan peranan yang besar sehingga tidak boleh putus dalam mengonsumsi ARV. Ibu rumah tangga penderita HIV percaya bahwa ARV merupakan penunjang jadi semua tergantung pada pola pemikiran dari seseorang. Ketika ibu rumah tangga penderita HIV percaya bahwa ARV dapat menimbulkan efek samping seperti penurunan hemoglobin (HB) maka hemoglobin ibu rumah tangga penderita HIV setelah minum ARV akan turun dan lain sebagainya. Sehingga control beliefs yang dilakukan ibu rumah tangga penderita HIV saat minum ARV adalah minum ARV tanpa menimbulkan efek samping. Control beliefs ibu rumah tangga penderita HIV juga terlihat bahwa ARV adalah terapi yang fungsional sehingga ibu rumah tangga penderita HIV harus merubah pikiran dan kepercayaannya bahwa ARV bukan obat tetapi vitamin karena ketika menganggap ARV sebagai vitamin maka rasa jenuh tidak akan muncul.

Perceived control behavior yang dimiliki ibu rumah tangga terlihat dari asumsi mereka terhadap kesulitan atau kemudahan yang dihadapi dalam konsumsi ARV. Kesulitan yang dihadapi ibu rumah tangga akan membuat terciptanya strategi baru yang menjadi antisipasi terhadap kesulitan yang akan dihadapi. Terdapat beberapa perbedaan pendapat mengenai tingkat kesulitan informan saat mengonsumsi ARV. Hal ini terlihat dari pernyataan ibu rumah tangga penderita HIV:

"Yaa... Susah mbak awal-awalnya. Tapi ya lama-lama nggak sih.. Dulu pas awal-awal aja mbak namanya kan juga butuh penyesuaian kan mbak. Yang semula gak pernah minum obat jadi harus minum obat tiap hari. Kan ya lama-lama ya bosen jenuh juga to.." (Ny A, 42 Tahun, P)

"Ya pertama itu kan dulu pertama terapi ARV itu rejimennya deviral neviral itu efek ke HB karena memang saya punya riwayat anemia. Tiga hari pertama itu HB ku drop 4. Akhirnya distop diganti rejimen yang jenisnya stafudin lamifudin sama neviral. Setelah 3 tahun itu aku mulai kena efek samping stafudin, dulu aku gemuk mbak.Trus akhirnya mulai tirus. Stafudin distop, aku akhirnya dikasih Tenofavir. Jadi tenofavir sama neviral. Baru pakek itu, baru pake beberapa kena efek samping. aku dites sama hepatitis $C$ positif. Akhirnya di stop 1 bulan dinetralkan dulu. Akhirnya di stop selama satu bulan sampai hasil normal. Akhirnya pakai rejimen lamifudin tenofavir sama evavafir dan alhamdulillah nyaman." (Ny B, 35 Tahun, P)

Dari wawancara terlihat bahwa ibu rumah tangga penderita HIV menganggap bahwa konsumsi ARV merupakan hal yang susah karena harus melakukan penyesuaian diri. Rasa jenuh mengonsumsi ARV pernah 
dirasakan oleh ibu rumah tangga penderita HIV dan lupa minum ARV pernah terjadi pada ibu rumah tangga penderita HIV. Efek samping dari ARV pernah dirasakan oleh ibu rumah tangga penderita HIV sehingga harus berganti jenis ARV. Pergantian ARV dilakukan sampai menemukan ARV yang cocok.

Strategi untuk menghadapi kesulitan terhadap konsumsi ARV dapat dilihat dari salah satu pernyataan ibu rumah tangga:

“...Iya, tapi tetep pakai alarm, soalnya kan kadang kita kalau keenakkan ngobrol kan juga lupa, enak-enak ngobrol nonton tivi..."(Ny A, 42 Tahun, P)

Ketika rasa jenuh muncul ibu rumah tangga penderita HIV berasumsi bahwa putusnya ARV bisa membuat kondisi kesehatan menurun dan akhirnya meninggal. Hal ini digunakan sebagai antisipasi dalam menghadapi rintangan agar tetap minum ARV. Perceived control behavior ibu rumah tangga penderita HIV juga terlihat ketika mereka menggunakan alarm untuk antisipasi mengingatkan bahwa sudah waktunya minum ARV karena takut lupa minun ARV saat asyik melakukan suatu aktifitas. Penggunaan alarm ibu rumah tangga penderita HIV ini dibenarkan oleh salah satu teman dekat ibu rumah tangga penderita HIV. Hal ini dapat dilihat dari pernyataan teman dekat ibu rumah tangga penderita HIV sebagai berikut:

“...biar gak lupa biasane sih dia pakai alarm mbak. Jadi nek pas keasyikan ngobrol, alarm bunyi bisa langsung minum ARV..."(Ny E, 36 tahun, $P$ )

Teman dekat ibu rumah tangga penderita HIV mengatakan bahwa ibu rumah tangga penderita HIV sudah memiliki kesadaran untuk minum ARV tetapi masih menggunakan alarm sebagai pengingat waktu untuk minum ARV. Bentuk perceived control behavior yang dilakukan ibu rumah tangga penderita HIV juga terlihat dari efek samping saat konsumsi ARV. Ibu rumah tangga penderita HIV melakukan strategi dengan cara minum ARV saat sudah dalam keadaan sangat mengantuk di malam hari sehingga ibu rumah tangga penderita
HIV tidak merasakan mabuk akibat efek samping yang ditimbulkan karena terbawa saat tidur. Hal ini dilakukan agar ketika bangun tidur keadaan ibu rumah tangga penderita HIV sudah segar kembali. Bentuk perceived control behavior lainnya yang dimiliki ibu rumah tangga penderita HIV terlihat saat akan melakukan kegiatan di luar kota. Ibu rumah tangga penderita HIV lebih mengutamakan ARV nya daripada perlengkapan lain. Keinginan untuk sehat yang dimiliki ibu rumah tangga penderita HIV membuat mau mengonsumsi ARV secara rutin. Tidak hanya itu, ibu rumah tangga penderita HIV mendapatkan pengalaman dari teman-temannya ketika yang putus ARV akhirnya kesehatan menjadi drop. Pengalaman inilah yang digunakan sebagai antisipasi ketika rasa jenuh dalam konsumsi ARV muncul.

Intention adalah sebuah niat yang dimiliki oleh individu untuk memunculkan perilaku tertentu. Hasil wawancara terlihat bahwa perbedaan pendapat antara ibu rumah tangga penderita HIV terkait niat yang dimiliki untuk konsumsi ARV hal ini dikarenakan latar belakang, control beliefs, perceived control behavior yang dimiliki setiap ibu rumah tangga penderita HIV berbeda.

Ibu rumah tangga penderita HIV memiliki niatan (intention) yang kuat untuk mengonsumsi ARV karena memiliki pengalaman berupa dampak yang diakibatkan putus ARV dari pengalaman suami dan teman-temannya. Tidak hanya pengalaman, ibu rumah tangga penderita HIV mendapatkan nasehat dan diingatkan untuk selalu konsumsi ARV dari lingkungan, keluarga dan Kelompok Dukungan Sebaya (KDS). Efek samping saat konsumsi ARV juga dihadapi oleh ibu rumah tangga penderita HIV tetapi tetap berniat untuk terus minum ARV. Mereka tangga penderita HIV melakukan pemeriksaan medis dan berkonsultasi dengan tenaga medis ketika efek samping ARV muncul. Besarnya niatan yang dimiliki ibu rumah tangga penderita HIV terlihat ketika harus beradaptasi dengan berganti-ganti jenis ARV terlebih dahulu sampai menemukan ARV yang tidak memiliki efek samping. Niatan yang dimiliki 
oleh ibu rumah tangga penderita HIV terlihat salah pada salah satu pernyataan ibu rumah tangga penderita HIV sebagai berikut:

"Ya kembali lagi semua niatan personal masing-masing mbak, kalau saya pribadi niatan kekuatan saya ada di anak-anak soalnya yang sering mengingatkan kadang ya anak saya dan suami saya..." (Ny C, 43 Tahun, $P$ )

Dari hasil wawancara terlihat bahwa niatan yang dimiliki ibu rumah tangga penderita HIV sudah baik. Niatan yang dimiliki oleh ibu rumah tangga penderita HIV tergantung pada personal individu masing-masing. Ketika ada permasalahan, ibu rumah tangga penderita HIV berniat untuk tetap minum ARV karena mendapatkan kekuatan terbesar dari anak dan suaminya.

Tabel 2. Emotional support yang diterima ibu rumah tangga penderita HIV

\begin{tabular}{lc}
\hline Bentuk emotional support & $\begin{array}{c}\text { Jumlah Ibu } \\
\text { rumah tangga } \\
\text { penderita HIV }\end{array}$ \\
\hline Mendapatkan nasehat & 3 \\
Diingatkan untuk minum obat & 3 \\
Mendapatkan semangat & 3 \\
Mendapatkan empati & 3 \\
Didoakan oleh pemuka agama & 1 \\
\hline
\end{tabular}

Berdasarkan tabel 2 menunjukkan bahwa semua ibu rumah tangga penderita HIV mendapatkan emotional support yang berasal dari keluarga, teman, dan lingkungan sekitar. Keluarga dan lingkungan tidak mempermasalahkan status HIV pada ibu rumah tangga penderita HIV. Pada jam minum obat maka keluarga akan mengingatkan untuk segera minum ARV. Perhatian juga didapatkan ketika keluarga sering mengingatkan untuk menjaga kondisi kesehatan informan dan mengingatkan untuk menghindari stres. Contoh cuplikan pernyataan ibu rumah tangga:

"Aku kan nggak bisa mbak minum obat pakai air dingin. Jadi nek pas aku tepar anakku godhokno (merebuskan) air anget mbak sama ngambilin ARVnya ke aku. Nek pas sakit gitu dia tau apa yang dia lakukan bunda tak buatkan the anget ya?"(Ny C, 43 Tahun, P)

Emotional support yang didapatkan oleh ibu rumah tangga penderita HIV menjadikan semangat tersendiri untuk selalu mengonsumsi ARV. Dukungan ini terasa ketika ibu rumah tangga penderita HIV mengalami rasa jenuh minum ARV atau saat mengalami efek samping dari konsumsi ARV.

Tabel 3. Esteem support yang diterima ibu rumah tangga penderita HIV

\begin{tabular}{lc}
\hline \multicolumn{1}{c}{ Bentuk esteem support } & $\begin{array}{c}\text { Jumlah Ibu } \\
\text { rumah tangga } \\
\text { penderita HIV }\end{array}$ \\
\hline $\begin{array}{l}\text { Tidak mendapatkan stigma } \\
\text { negatif }\end{array}$ & 3 \\
$\begin{array}{l}\text { Tidak mendapat } \\
\text { diskriminasi }\end{array}$ & 3 \\
$\begin{array}{l}\text { Mendapatkan anggapan } \\
\text { bahwa HIV merupakan } \\
\text { penyakit yang biasa }\end{array}$ & 2 \\
\hline
\end{tabular}

Bentuk esteem support yang diperoleh ibu rumah tangga penderita HIV sama. Hasil wawancara menunjukkan ibu rumah tangga penderita HIV mendapat esteem support berupa sikap keluarga dan tetangga yang tetap mau makan masakan ibu rumah tangga penderita HIV dan anak dari mereka mau melakukan kegiatan bersama ibu rumah tangga penderita HIV. Ketika ibu rumah tangga penderita HIV tidak mendapat diskriminasi membuat rasa percaya diri ibu rumah tangga penderita HIV ada dan mempunyai keyakinan bahwa penyakit HIV itu seperti pada umumnya yang membutuhkan pengobatan secara rutin. Hal ini terlihat dari pernyataan ibu rumah tangga penderita HIV:

"biasa sih kalau mereka pun ada pertemuan apa, kalau saya masak apa ya dimakan saya didepan. Anaknya saya ajak juga boleh. Jadi ya dalam hatiku aku merasa nek nggak dikucilkan walaupun aku sekarang kena HIV" (Ny A, 42 Tahun, $P$ )

Adanya esteem support yang didapatkan ibu rumah tangga penderita HIV, berdampak pada saat acara keluarga, ibu rumah tangga 
penderita HIV menjadi tidak malu untuk minum ARV di depan keluarganya. Bentuk esteem support lainnya terlihat bahwa ibu rumah tangga penderita HIV mendapat kepercayaan diri dari tetangga dan keluarga yang selalu mengatakan bahwa penyakit HIV itu seperti penyakit diabetes yang membutuhkan obat secara rutin harus dikonsumsi.

Tabel 4. Tangible instrumental support yang diterima ibu rumah tangga penderita HIV

\begin{tabular}{lc}
\hline \multicolumn{1}{c}{$\begin{array}{c}\text { Bentuk tangiable } \\
\text { instrumental support }\end{array}$} & $\begin{array}{c}\text { Jumlah Ibu } \\
\text { rumah tangga } \\
\text { penderita HIV }\end{array}$ \\
\hline $\begin{array}{l}\text { Anak mendapatkan uang } \\
\text { saku dari keluarga } \\
\text { Mendapatkan pinjaman }\end{array}$ & 2 \\
ARV & 1 \\
$\begin{array}{l}\text { Dibelikan pulsa listrik oleh } \\
\text { keluarga }\end{array}$ & 1 \\
$\begin{array}{l}\text { Mendapatkan makanan dari } \\
\text { tetangga }\end{array}$ & 3 \\
$\begin{array}{l}\text { Mendapatkan HP dari } \\
\text { teman }\end{array}$ & 1 \\
Dibelikan pulsa oleh teman & 1 \\
\hline
\end{tabular}

Bentuk tangiable instrumental support yang diperoleh ibu rumah tangga penderita HIV sangat beragam. Bantuan langsung yang terlihat wujudnya berupa uang diperoleh oleh ibu rumah tangga penderita HIV dari keluarga, teman dan lingkungan tempat tinggal. Bantuan berupa uang yang diterima oleh ibu rumah tangga penderita HIV, terlihat dari pernyataan sebagai berikut:

“...Kalau materi ya ada lah mbak dari adekku. Tapi ya nggak full mbak. Kalau untuk bantu-bantu apa kayak beli apa sih, beli listrik ada lah .Lumayan lah mbak apalagi pas masa masa gak ada uang." (Ny B, 35 Tahun, P)

Hal ini sangat membantu ibu rumah tangga penderita HIV karena dengan adanya bantuan uang, ibu rumah tangga penderita HIV dapat menyisihkan sedikit uang untuk membayar loket pendaftaran ketika akan mengambil ARV.

Bentuk informational support yang diperoleh terlihat dari pernyataan salah satu
Tabel 5. Informational support yang diterima ibu rumah tangga penderita HIV

\begin{tabular}{lc}
\hline $\begin{array}{c}\text { Bentuk informational } \\
\text { support }\end{array}$ & $\begin{array}{c}\text { Jumlah Ibu } \\
\text { rumah tangga } \\
\text { penderita HIV }\end{array}$ \\
\hline Mendapatkan nasehat & 3 \\
Mendapatkan informasi & 3 \\
Mendapatkan buku tentang & 1 \\
HIV AIDS & \\
\hline
\end{tabular}

ibu rumah tangga penderita HIV sebagai berikut:

"Pas dulu kan jamannya stigma masih tinggi kan ya mbak.. Mau minta ke tenaga medis mesti ada tanya tanya besar. Akhirnya aku ke teman-teman juga. e...bisa minta gak buku tentang HIV. Akhirnya ya dikasih mbak 1 paket. Ada HIV dasar, HIV dan TB, HIV co infeksi dan segala macem." (Ny B, 35 Tahun, $P$ )

Informational support yang diperoleh ibu rumah tangga penderita HIV berasal dari teman dan KDS. Ibu rumah tangga penderita HIV mendapatkan informasi tentang manfaat dan bahaya putus ARV ketika ada pertemuan di KDS selama 1 kali dalam sebulan. Di dalam pertemuan itu biasanya ada sosialisasi yang dilakukan oleh tenaga kesehatan. Dari sosialisasi itu, mereka menjadi lebih percaya akan manfaat ARV.

Ibu rumah tangga penderita HIV mendapatkan network support dari KDS. Ibu rumah tangga penderita HIV memiliki rasa nyaman ketika berinteraksi dengan sesama penderita HIV karena dengan rasa empati yang diberikan oleh penderita HIV berbeda dengan rasa empati yang berasal dari yang bukan penderita HIV. Ketika ingin berkeluh kesah, ibu rumah tangga penderita HIV mendapatkan dari sesama penderita HIV dan selalu mengingatkan minum ARV karena sama-sama merasakan apa yang dirasakan.

\section{PEMBAHASAN}

Control beliefs menurut Ajzen (2005) adalah suatu keyakinan seorang bahwa perilaku yang dilaksanakan diperoleh dari berbagai hal seperti dari keterampilan, 
pengetahuan, maupun pengalaman. Pengalaman individu dapat berasal dari pengalaman pribadi dan pengalaman orang lain dapat mempengaruhi tingkat kepercayaan diri untuk mengonsumsi ARV.

Control beliefs yang dimiliki oleh ibu rumah tangga penderita HIV berasal dari pengalaman almarhum suami informan primer dan dari teman-teman ketika putus ARV maka kesehatan akan menjadi turun dan akhirnya meninggal. Pengalaman inilah yang dijadikan ibu rumah tangga penderita HIV sebagai pengingat diri untuk tidak putus minum ARV. Adanya peningkatan pengetahuan yang dimiliki oleh ibu rumah tangga penderita HIV juga berdampak pada keyakinan (control beliefs) terhadap suatu konsumsi ARV. Ibu rumah tangga penderita HIV mendapatkan pengetahuan tentang manfaat dan dampak ARV dari berbagai media informasi seperti mengikuti seminar dan pelatihan, melalui media sosial, dan mengikuti kegiatan yang diadakan oleh KDS. Pemanfaatan media sosial dan KDS yang dilakukan oleh ibu rumah tangga penderita HIV untuk meningkatkan pengetahuan dan pengalaman. Ibu rumah tangga penderita HIV menjadi tahu bahwa ketika putus ARV akan berakibat pada penurunan kesehatan.

Hasil penelitian tentang peningkatan pengetahuan berpengaruh pada keyakinan ini diperkuat juga pada penelitian yang dilakukan oleh Sofa (2015) bahwa responden yang memiliki pengetahuan yang baik tentang HIV AIDS maka perilaku seksual yang dilakukan lebih sedikit dibandingkan dengan responden yang pengetahuan terkait HIV AIDS rendah. karena informan memiliki keyakinan. Semakin tinggi keyakinan yang dimiliki maka semakin rendah perilaku seksual yang akan dilakukan.

Hasil penelitian ini menunjukkan bahwa untuk meningkatkan control beliefs tidak hanya berasal dari dalam individu tetapi juga bisa berasal dari lingkungan sekitar. Individu dapat mengambil pengalaman yang dialami oleh lingkungan sekitar untuk memperkuat control beliefs. Peran lingkungan sekitar dalam peningkatan control beliefs dari individu misalnya dengan memberikan dukungan sosial pada individu. Ketika individu sedang di masa jenuh minum ARV maka sekitar dapat mengingatkan lagi manfaat, dampak yang ditimbulkan ketika putus ARV dan memberikan motivasi. Adanya perhatian dari lingkungan sekitar akan membuat ibu rumah tangga penderita HIV mau mengatasi permasalahan yang dihadapi.

Perceived control behavior menurut Ajzen (2005) adalah kemudahan atau kesulitan untuk menampilkan suatu perilaku serta antisipasi dalam menghadapi rintangan yang dapat berasal dari pengalaman seseorang. Ibu rumah tangga penderita HIV memiliki pengalaman dan latar belakang berbeda bisa mempengaruhi pada perceived control behavior yang berbeda juga terhadap konsumsi ARV. Ibu rumah tangga penderita HIV menghadapi kesulitan saat akan minum ARV seperti perasaan jenuh minum ARV, hambatan dan diskriminasi yang didapatkan. Pada awalnya, minum ARV pada ibu rumah tangga penderita HIV merupakan hal yang sulit karena harus melakukan penyesuaian diri.

Hasil penelitian ini terlihat bahwa upaya untuk meningkatkan perceived behavioral control seseorang dapat berasal dari dalam individu sendiri dengan menggunakan pengalaman terkait hambatan yang pernah dihadapi sehingga memunculkan strategi baru. Strategi baru ini yang digunakan oleh ibu rumah tangga penderita HIV ketika ada hambatan yang muncul kembali. Peningkatan perceived behavioral control dapat berasal dari lingkungan sekitar. Dukungan sosial yang diberikan pada individu misalnya sikap empati, sikap pengertian, memberikan nasehat dan informasi, memberikan bantuan dalam wujud barang. Ketiadaan dukungan sosial dan adanya diskriminasi yang dialami oleh individu dapat berdampak pada perceived behavioral control yang dimiliki individu. Perceived behavioral control pada individu juga dipengaruhi oleh control beliefs. Ketika individu mempunyai control beliefs yang kuat maka individu dapat mengatasi hambatan yang dihadapi dengan baik. Adanya persepsi kemudahan atau kesulitan (perceived behavioral control) yang dihadapi oleh individu digunakan untuk antisipasi dalam menghadapi permasalahan yang akan 
datang. Hasil penelitian ini sesuai dengan penelitian yang dilakukan oleh Khamidah (2011) bahwa ibu rumah tangga seringkali menghadapi kesulitan untuk menolak berhubungan seksual pada suaminya yang sudah berisiko HIV. Sulitnya ibu rumah tangga menolak sebagai tolak ukur bahwa ibu rumah tangga tersebut mengalami kesulitan untuk dapat mengendalikan perilaku seksual berisiko. Hal ini biasanya dipengaruhi oleh pengalaman, gender, pengetahuan, dan control beliefs yang dimiliki oleh ibu rumah tangga.

Hasil penelitian pada niatan (intention) secara umum menggambarkan bahwa ibu rumah tangga penderita HIV mempunyai niatan untuk terus minum ARV secara berkelanjutan. Tingginya niatan yang dimiliki karena ibu rumah tangga penderita HIV memiliki pengetahuan terkait HIV AIDS yang baik, pengalaman tentang konsumsi ARV, control beliefs dan asumsi yang baik bahwa ibu rumah tangga penderita HIV mampu saat menghadapi permasalahan dalam minum ARV. Niatan yang dimiliki dapat memunculkan perilaku seperti konsumsi ARV. Semakin kuat niatan untuk minum ARV maka akan semakin kuat niat dan keyakinan ibu rumah tangga penderita HIV untuk konsumsi ARV. Tinggi rendahnya niatan yang dimiliki individu dilihat dari cara menghadapi hambatan. Ketika hambatan yang dihadapi individu semakin banyak dan individu merasa mampu mengatasi hambatan itu dan tetap minum ARV maka individu tersebut memiliki niatan yang tinggi. Adanya niatan yang kuat akan meminimalkan individu "goyah" ketika ada hambatan yang muncul dalam melakukan perubahan perilaku.

Hasil penelitian ini diperkuat oleh Tiaraningrum (2012) bahwa pasangan ODHA yang memiliki pengetahuan, sikap positif yang tinggi, control belief dan perceived control yang baik dapat berdampak pada niat yang semakin tinggi untuk melakukan pencegahan perilaku berisiko.

Ibu rumah tangga penderita HIV pada penelitian ini sudah mempunyai kesadaran untuk minum ARV. Adanya kesadaran diri berasal dari dalam dan luar individu. Perubahan perilaku individu tergantung pada pengetahuan, pengalaman, kepercayaan, persepsi terhadap masalah yang dihadapi dan niatan individu. Dukungan sosial juga berperan penting dalam perubahan perilaku individu. Ketika individu mendapatkan banyak hambatan maka individu semakin banyak membutuhkan dukungan yang berasal dari lingkungan sekitar individu. Dukungan sosial yang diberikan membuat individu percaya bahwa dapat mengatasi permasalahan yang ada sehingga semakin kuat keinginan untuk minum ARV. Pengalaman ibu rumah tangga penderita HIV didapatkan ketika melihat banyak yang putus ARV kemudian kesehatan menurun dan akhirnya drop inilah yang juga dijadikan alasan untuk terus mau konsumsi ARV. Ketika informan merasa jenuh minum ARV maka kan memanfaatkan dukungan sosial yang didapatkan sehingga menjadi semangat lagi minum ARV.

Emotional support adalah dukungan yang diterima berupa sikap perhatian empati, yang berasal dari lingkungan sekitar (Sarafino, 1994). Hasil penelitian menunjukkan bahwa informan mendapatkan emotional support dari lingkungan sekitar. Ibu rumah tangga penderita HIV sering dinasehati dan diingatkan untuk minum ARV. Dukungan ini dapat dikatakan sebagai sumber kekuatan utama bagi ibu rumah tangga penderita HIV. Dukungan secara emosi yang didapatkan membuat ibu rumah tangga penderita HIV merasa tidak sendirian karena orang lain juga ikut merasakan apa yang dirasakan oleh ibu rumah tangga penderita HIV. Dukungan emosional juga sangat berguna ketika informan mengalami rasa jenuh minum ARV maka lingkungan akan mengingatkan dan ibu rumah tangga penderita HIV menjadi semangat minum ARV lagi.

Penelitian ini sesuai dengan penelitian yang dilakukan oleh O'Brien dkk (2009) bahwa dengan adanya dukungan emosional mampu mengurangi rasa depresi dan stress yang dialami penderita HIV AIDS dan dapat berdampak pada meningkatnya kulitas hidup penderita HIV AIDS.

Esteem Support adalah dukungan dari lingkungan sekitar yang melibatkan suatu sikap atau penghormatan positif pada seseorang agar dapat meningkatkan 
kepercayaan diri. Bentuk esteem support yang didapatkan ibu rumah tangga penderita HIV beragam. Hasil penelitian menunjukkan bahwa ketika seseorang mendapatkan esteem support yang baik maka ibu rumah tangga penderita HIV akan merasa bahwa penyakitnya adalah penyakit yang biasa dan tidak perlu dijauhi karena dengan sikap percaya diri yang dimiliki ibu rumah tangga penderita HIV akan membuat tidak stres sehingga kualitas hidup ibu rumah tangga penderita HIV lebih baik lagi dan informan mau terus mengonsumsi ARV. Penelitian ini sesuai dengan penelitian yang dilakukan oleh Tylor (2006) bahwa dengan adanya dukungan berupa peningkatan harga diri membuat ODHA bisa menerima keadaan dirinya dan akan timbul kesadaran untuk mempertahankan hidup menghadapi permasalahan yang ada.

Tangible instrumental support adalah dukungan yang diberikan lingkungan sekitar dalam bentuk pemberian barang yang berwujud. Hasil penelitian Basanti dan Nomathemba (2008) menggambarkan bahwa salah satu dukungan yang dibutuhkan penderita HIV AIDS untuk menjalani perawatan di rumah adalah dengan dukungan berupa bantuan pengobatan, keuangan, dan makanan karena tidak semua HIV AIDS memiliki pemasukan keuangan. Pada penelitian ini, kedua informan mendapat bantuan berupa uang untuk sangu anaknya. Bantuan uang tersebut berguna untuk meringankan beban keuangan ibu rumah tangga penderita HIV. Ibu rumah tangga penderita HIV juga pernah mendapatkan bantuan berupa pinjaman ARV ketika stok ARV di Indonesia menipis. Pinjaman ARV ini sangat berguna karena ibu rumah tangga penderita HIV menjadi tidak jadi putus ARV. Tangiable instrumental support yang diterima oleh ibu rumah tangga penderita HIV sangat berguna karena ketika merasakan kesulitan yang berkaitan dengan kondisi materi, ibu rumah tangga penderita HIV akan merasa terbantu, apalagi ibu rumah tangga penderita HIV tidak bekerja. Tangible instrumental support begitu terasa ketika ibu rumah tangga penderita HIV berada di masa sulit tidak memiliki uang.

Informational support adalah dukungan berupa pemberian informasi yang dibutuhkan oleh seseorang. Informational support pada penelitian ini didapatkan dari KDS yang diikuti. Informational support yang diterima sangat bermanfaat karena saat itu stigma terhadap penderita HIV AIDS masih tinggi sehingga tidak memungkinkan untuk mendapatkan informasi HIV AIDS melalui layanan kesehatan. Adanya dukungan informasi yang didapatkan ibu rumah tangga penderita HIV berdampak pada peningkatan pengetahuan. Ibu rumah tangga penderita HIV yang semula tidak tahu tentang HIV AIDS menjadi tahu. Peningkatan pengetahuan ini yang membuat Ibu rumah tangga penderita HIV menjadi lebih sadar dan menjadi lebih tahu cara perawatan dan pengobatan yang dilakukan, cara pemenuhan gizi dan juga cara penularannya sehingga mempunyai rasa kehati-hatian dalam bertindak.

Hasil penelitian ini sesuai dengan penelitian yang dilakukan oleh Siegel dalam Tylor (2006) bahwa dukungan informasi digunakan sebagai peredam stress penderita AIDS yang berkaitan dengan timbulnya gejala dan keluhan yang dialami. Adanya informational support dapat dijadikan tambahan informasi pada keluarga dan lingkungan penderita HIV AIDS sehingga menjadi tahu penyakit HIV AIDS dan tidak memberikan stigma atau diskriminasi pada penderita HIV AIDS.

Networks support adalah dukungan yang merupakan adanya rasa keanggotaan yang didapatkan dari komunitas. Informan mendapatkan networks support dari KDS, media sosial dan couple community. Networks support paling penting bagi ibu rumah tangga penderita HIV karena walaupun bersama orang lain nyaman tetapi dengan komunitas jauh lebih nyaman. Adanya komunitas merasa bahwa samasama merasakan tentang penyakit HIV. Networks support juga berperan untuk meningkatkan informasi baru terkait penyakit HIV AIDS di Indonesia dan bisa mengetahui perkembangan terbaru penyakit HIV AIDS yang ada. Networks support juga berperan untuk meningkatkan rasa solidaritas keanggotaan kelompok.

Pada dukungan ini, ibu rumah tangga penderita HIV merasa bahwa dukungan dari komunitas merupakan hal yang paling 
penting setelah dukungan secara emosi karena ketika misalnya ibu rumah tangga penderita HIV tidak mendapat dukungan dari keluarga maka akan didukung dari lingkungan komunitas. Komunitas juga berperan dalam peningkatan pengetahuan penyakit HIV AIDS dan keyakinan pada individu terhadap peran dan manfaat dari terapi yang dilakukan. Hasil penelitian ini sesuai dengan penelitian yang dilakukan oleh Rahadatu (2016) bahwa ada hubungan positif antara dukungan sosial dengan kualitas hidup pada ODHA pada KDS Solo Plus yaitu semakin baik dukungan yang berasal dari KDS Solo Plus maka kualitas hidup ODHA semakin meningkat.

Peran dukungan sosial yang diterima informan sama. Informan berpendapat bahwa yang paling penting adalah dukungan secara emosional dan dukungan di komunitas. Dukungan sosial yang dia terima informan sangat bermanfaat ketika pertama kali terkena HIV belum mendapatkan informasi akhirnya mendapat informasi terkait HIV dari teman-teman dan ibu rumah tangga penderita HIV menjadi tahu yang harus dilakukan. Ibu rumah tangga penderita HIV menjadi rutin minum ARV. Emotional support dan network support yang paling penting bagi ibu rumah tangga penderita HIV karena dengan adanya emotional support ibu rumah tangga penderita HIV merasa diperhatikan dan dipahami oleh lingkungannya. Network support juga paling penting bagi ibu rumah tangga penderita HIV karena adanya kenyamanan pada anggota komunitas HIV AIDS karena merasa mempunyai kesamaan yaitu menjadi penderita HIV AIDS. Peranan dukungan sosial bagi ibu rumah tangga penderita HIV yang diterima diibaratkan sebagai terapi penunjang, karena tanpa adanya dukungan sosial maka untuk melakukan terapi utama seperti minum ARV, melakukan pengobatan rutin menjadi hal yang sulit. Emotional support dan network support paling penting karena adanya empati dari seseorang bisa membuat dirinya mau mengonsumsi ARV secara rutin. Hal ini berguna saat ibu rumah tangga penderita HIV mengalami masalah dan jenuh minum ARV maka dengan perhatian dari orang lain membuat ibu rumah tangga penderita HIV lebih semangat. Komunitas merupakan keluarga kedua ibu rumah tangga penderita HIV keluarga dan adanya dukungan informasi dari temanteman dan komunitas, ibu rumah tangga penderita HIV menjadi tahu ilmu terbaru mengenai HIV AIDS. Adanya network support sebagai penghibur diri karena ibu rumah tangga penderita HIV merasa bahwa teman-teman komunitas peduli dan bisa membuat tertawa dengan bahan bercandaan salah satu teman komunitas, inilah yang digunakan ibu rumah tangga penderita HIV sebagai antisipasi stres.

Dukungan sosial sangat diperlukan bagi ibu rumah tangga penderita HIV karena ibu rumah tangga penderita HIV dapat semangat menjalani kegiatan yang berpengaruh pada konsumsi ARV. Ketika rasa jenuh minum ARV datang, ibu rumah tangga penderita HIV kembali mempunyai control beliefs yang berasal dari dukungan sosial tersebut, sehingga menjadi yakin terhadap manfaat minum ARV secara rutin yang dilakukan dan menjadi bisa menghadapi permasalahan yang ada.

\section{KESIMPULAN}

Kontrol kepercayaan diri dan keyakinan (control beliefs) untuk minum ARV yang dimiliki ibu rumah tangga penderita HIV di Surabaya sudah tinggi. Ibu rumah tangga penderita HIV percaya bahwa minum ARV secara teratur mampu membuat mereka lebih sehat dan produktif. Adanya hambatan untuk minum ARV seperti rasa jenuh dan efek samping ARV tidak menghalangi ibu rumah tangga penderita HIV untuk minum ARV. Niatan yang dimiliki ibu rumah tangga penderita HIV kuat bahwa akan terus melakukan minum ARV walaupun menghadapi berbagai rintangan di masa akan datang. Konsumsi ARV ini dilakukan karena mendapatkan pengalaman dari suami dan teman-temannya yang putus ARV berdampak pada kondisi kesehatan yang menurun dan akhirnya meninggal. Tidak hanya itu, pengetahuan yang dimiliki ibu rumah tangga penderita HIV terhadap penyakit HIV AIDS berdampak pada niatan untuk mengonsumsi ARV. Semakin tinggi 
pengetahuan yang dimiliki, maka semakin tinggi niat untuk konsumsi ARV secara rutin.

Bentuk dukungan sosial yang diterima ibu rumah tangga penderita HIV di Surabaya berbagai macam seperti mendapat dukungan emosional, dukungan dalam bentuk bantuan barang yang berwujud, dukungan informasi, dukungan kepercayaan diri dan mendapat dukungan dari komunitas sesama penderita HIV. Dukungan yang paling berpengaruh bagi ibu rumah tangga penderita HIV adalah dukungan secara emosional dan dukungan di komunitas. Peran dukungan sosial yang diterima ibu rumah tangga penderita HIV di Surabaya adalah dengan adanya dukungan sosial, dapat meningkatkan kepercayaan untuk terus minum ARV secara rutin.

\section{DAFTAR PUSTAKA}

Ajzen, I 2005.Attitude, Personality And Behavior Second Edition. New York: Open University Press.

Basanti and Namathemba. 2010. The experience of people living with HIV/ AIDS and of their direct informal caregivers in a resource-poor setting. Tersedia di https://www.ncbi.nlm.nih. gov/pmc/articles/PMC2896341/[diakses tanggal 20 Desember 2016].

Depkes RI. 2003. Pedoman Promosi Kesehatan Nasional. Jakarta: Departemen Kesehatan Republik Indonesia.

Dinkes Kota Surabaya. 2014. Laporan Tahunan Dinas Kesehatan Kota Surabaya Tahun 2014. Surabaya: Dinas Kesehatan Kota Surabaya.

Hollen, V. C. 2010. HIV/AIDS and the Gendering of Stigma in Tamil Nadu South India. Cult Med Psychiatry.
O'Brien, K.K., Davis, M.A., Strike, C., Young, L.N., and Bayoumi, M.A. 2009. Putting episodic disability into context: a qualitative study exploring factors that influence disability experienced by adults living with HIV/AID Tersedia di http:// link.springer.com/article/10.1186/17582652-12-30[diakses tanggal 20 Desember 2016].

Kemenkes RI. 2013. Statistik Kasus HIV/AIDS di Indonesia Dilapor s/d Desember2013. Jakarta: Direktorat Jenderal Pengendalian Penyakit Dan Penyehatan Lingkungan.

Kemenkes RI. 2014. Statistik Kasus HIV/ AIDS di Indonesia dilapor s/d September 2014.Jakarta:Ditjen PP \& PL Kemenkes RI.

Moleong, L. 2009. Metodologi Penelitian Kualitatif. Bandung: Rosda Karya.

Sarafino, E.P. 1994. Health Psychology: Biopsychological Interaction. Kanada: John Wiley \& Sons, Inc.

Sofa, Marya. 2015. Peranan Pengetahuan, Keyakinan Dan Sikap Mengenai HIVAIDS Terhadap Perilaku Seksual Remaja Di Kabupaten Bungo Tahun 2013. Research of Applied Science and Education, Volume: V8.i4 (199-209). Tersedia di: http://ejournal.kopertis10. or.id/index.php/jit/article/view/16/15.

Tiaraningrum, N.A. 2012. Pemahaman Pengendalian (Perceived Control) Perilaku Seksual Berisiko Pasangan ODHA Dalam Upaya Pencegahan Penularan HIV. Skripsi. Universitas Airlangga.

Tylor, S.E. 2006. Health Psychology Psycomunology, AIDA, Cancer and Arthritis. New York: McGraw Hill. 